\title{
Pancreatic cancer: treatment approaches and trends
}

\author{
Nabyla Paixão Pereira, José Raimundo Corrêa \\ Laboratory of Microscopy and Microanalyses, Group of Applied Chemotherapy and Fluorescent Probes, Department of Cellular \\ Biology, Institute of Biological Science, University of Brasilia, Brasilia, DF 70910-900, Brazil. \\ Correspondence to: Dr. José Raimundo Corrêa, Laboratory of Microscopy and Microanalyses, Group of Applied Chemotherapy \\ and Fluorescent Probes, Department of Cellular Biology, Institute of Biological Science, Campus universitário Darcy Ribeiro, \\ University of Brasilia, Brasilia, DF 70910-900, Brazil. E-mail: correa@unb.br
}

How to cite this article: Pereira NP, Corrêa JR. Pancreatic cancer: treatment approaches and trends. J Cancer Metastasis Treat 2018;4:30. http://dx.doi.org/10.20517/2394-4722.2018.13

Received: 27 Feb 2018 First Decision: 28 Mar 2018 Revised: 8 Jun 2018 Accepted: 11 Jun 2018 Published: 25 Jun 2018

Science Editor: Shuen-Kuei Liao Copy Editor: Jun-Yao Li Production Editor: Cai-Hong Wang

\begin{abstract}
Pancreatic cancer is one of the most challenging diseases due to its often late diagnose which results in limited therapeutic options and poor prognosis. To date, the only curative treatment is complete tumor removal surgery but only a few patients are eligible to do it. The median survival period after surgery followed by chemotherapy adjuvant treatment is about 2 years. Since its approval by the FDA, Gemcitabine has become the first-line chemotherapy agent for treatment of advanced pancreatic cancer. The FOLFIRINOX regimen is also used as a treatment scheme for pancreatic cancer; however, this regimen has resulted in small improvements in overall patient's survival. It is appropriated to clarify that the FOLFIRINOX regimen can only be administered in patients with good performance status. Due to the absence of outstanding result after patient's treatment with diverse chemotherapeutic agents combinations or unsuccessful administration of single-agent drugs to treat pancreatic cancer, the immunotherapy has become a new hope. A more comprehensive understanding of cancer microenvironment and the chemical communication between cancer cells and immune cells can result in new therapeutic approaches that will improve the elimination of pancreatic cancer cells, enhancing life quality for these patients and increasing the overall survival.
\end{abstract}

Keywords: Pancreatic cancer, chemotherapy, gemcitabine, immunotherapy

\section{INTRODUCTION}

In recent decades the worldwide incidence of cancer has increased substantially. It has been estimated that 609,640 Americans will die from cancer this year ${ }^{[1]}$ and pancreatic cancer is ranked in the fourth position among cancer-related deaths in the United States ${ }^{[2-5]}$. This cancer type is responsible for 331,000 deaths per year ${ }^{[6]}$, and according to GLOBOCAN, 2016 almost 340,000 new cases of pancreatic cancer are diagnosed each year worldwide.

\footnotetext{
(a) 8

(C) The Author(s) 2018. Open Access This article is licensed under a Creative Commons Attribution 4.0 International License (https://creativecommons.org/licenses/by/4.0/), which permits unrestricted use, sharing, adaptation, distribution and reproduction in any medium or format, for any purpose, even commercially, as long as you give appropriate credit to the original author(s) and the source, provide a link to the Creative Commons license, and indicate if changes were made.
}

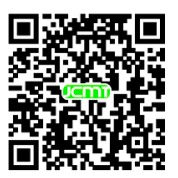


Pancreatic cancer is more common in elderly persons (between 60 and 80 years) and some studies have shown an increased incidence among diabetes ${ }^{[7,8]}$ or chronic pancreatitis patients ${ }^{[2,9,10]}$. Both environmental and inherited factors ${ }^{[1]}$ can contribute to the development of this disease and the most common risk factors associated to this type of cancer are smoking ${ }^{[12,13]}$ and overweight obesity ${ }^{[14]}$.

The adenocarcinoma is the most common pancreatic cancer, representing $85 \%$ of all cases ${ }^{[15]}$. Furthermore, the pancreatic adenocarcinoma remains one of the most challenging malignancies with limited therapeutic options and poor prognosis ${ }^{[3]}$ because it is usually diagnosed at an advanced stage ${ }^{[16]}$. This aspect partially can be explained by the fact that early stages of pancreatic cancer often present none or nonspecific symptoms, which can be translated in diagnosis challenges ${ }^{[12]}$.

Normally, advanced pancreatic cancer patients can present symptoms like nausea, vomiting, bloating, unexplained weight loss, jaundice, abdominal pain, dyspepsia and sometimes pancreatitis ${ }^{[9]}$. Moreover, 70\% of patients present diabetes mellitus, usually with a diabetes history of less than 2 years ${ }^{[17]}$. The poor prognosis is also attributed to the high incidence of metastasis, leading to an aggressive disease course combined with the limited efficacy of systemic treatments ${ }^{[5]}$.

Surgery procedures are considered the most effective treatment and the only curative intervention but only $20 \%$ of patients are fit for it based on disease staging ${ }^{[4]}$ and up to $80 \%$ of these patients relapse. When compared to other resected solid tumors, the poorest outcomes are observed in patients with resected pancreatic cancer. After surgery, those resected patients are selected for adjuvant therapy with chemoradiation or chemotherapy alone and they present a median survival post-surgery combined with adjuvant therapy averaging 2 years ${ }^{[14]}$, with only $20 \%$ of patients reaching 5 -year survival rate ${ }^{[18]}$. Regarding that, there are some studies with neoadjuvant chemotherapy administered in patients with resectable, borderline resectable or locally advanced disease aiming to increase resectability by achieving higher margin-negative resections and conversion rates ${ }^{[19]}$.

According to the American Cancer Society, the 5-year relative survival of pancreatic cancer patients is $29 \%$ for localized stage at diagnose period, $11 \%$ for regional stage and only $3 \%$ for distant stage ${ }^{[20,21]}$. These statistical data indicate that there is an increased need for development of efficient and well-tolerated treatment options. This work intends to summarize the approved adjuvant chemotherapy approaches [Table 1] for advanced pancreatic cancer and some immunotherapy treatment trends for this aggressive and devastating disease.

\section{TREATMENT OPTIONS}

Treatment of pancreatic cancer is multimodal, and most patients will receive more than one type. The primary and only curative intervention is surgery. In sequence, it includes adjuvant (treatment given after primary treatment) chemotherapy and/or radiation therapy, or palliative care depending on the stage of cancer, according to the staging system developed by American Joint Committee on Cancer, which is now in the 8th edition. Based on the cancer stage the patient will be directed to a kind of treatment. This staging system takes into account the TNM status which means: $\mathrm{T}$ - primary tumor size; $\mathrm{N}$ - lymph node involvement; $\mathrm{M}$ - distant metastasis [Table 2] ${ }^{[18]}$.

As mentioned, different treatment guidelines are used for each stage. Frequently, stage II (resected lesions) is treated by surgery and adjuvant chemotherapy, sometimes including chemoradiation; Stage III (locally advanced) chemotherapy with or without chemoradiation and stage IV (metastatic) with chemotherapy ${ }^{[22]}$.

\section{SURGERY}

Pancreatic cancer patients are subdivided into four groups: resectable, borderline resectable, locally advanced nonresectable, and metastatic. Cancer that is confined to the pancreas without significant involvement of nearby 
Table 1. Summary of chemotherapy approaches

\begin{tabular}{|c|c|c|c|c|c|c|}
\hline $\begin{array}{l}\text { Comercial } \\
\text { name }\end{array}$ & Composition & FDA approval & Indication & $\begin{array}{l}\text { Survival rate at } \\
12 \text { months }\end{array}$ & $\begin{array}{c}\text { Median } \\
\text { progression free } \\
\text { survival }\end{array}$ & $\begin{array}{c}\text { Median overall } \\
\text { survival }\end{array}$ \\
\hline Gemzar & Gemcitabine & 1996 & $\begin{array}{l}\text { Advanced } \\
\text { pancreatic cancer }\end{array}$ & $\begin{array}{l}18 \% \text { compared } \\
\text { to } 2 \% 5-\mathrm{FU}\end{array}$ & - & 5.65 months \\
\hline Abraxane & $\begin{array}{l}\text { Paclitaxel albumine- } \\
\text { stabilized } \\
\text { nanoparticle }\end{array}$ & $\begin{array}{l}2013 \text { in } \\
\text { combination with } \\
\text { gemcitabine }\end{array}$ & $\begin{array}{l}\text { Metastatic } \\
\text { pancreatic cancer }\end{array}$ & $\begin{array}{l}35 \% \text { compared } \\
\text { to } 22 \% \text { of } \\
\text { gemcitabine } \\
\text { alone }\end{array}$ & 5.5 months & 8.5 months \\
\hline FOLFIRINOX & $\begin{array}{l}\text { 5-FU, } \\
\text { leucovorin, } \\
\text { Irinotecan and } \\
\text { oxaliplatin }\end{array}$ & - & $\begin{array}{l}\text { Metastatic } \\
\text { pancreatic } \\
\text { cancer of good } \\
\text { performance } \\
\text { status patients }\end{array}$ & $\begin{array}{l}48 \% \text { compared } \\
\text { to } 20 \% \text { of } \\
\text { gemcitabine }\end{array}$ & 6.4 months & 11.1 months \\
\hline Onyvide & $\begin{array}{l}\text { Nanolipossomal } \\
\text { irinotecan }\end{array}$ & $\begin{array}{l}2015 \text { in } \\
\text { combination } \\
\text { with + 5-FU } \\
+ \text { leucovorin }\end{array}$ & $\begin{array}{l}\text { Gemcitabine } \\
\text { resistant } \\
\text { Advanced } \\
\text { metastatic } \\
\text { pancreatic cancer }\end{array}$ & $\begin{array}{l}26 \% \text { compared } \\
\text { to } 16 \% \text { in } 5-F U \\
+ \text { folinic acid }\end{array}$ & 3.1 months & 6.1 months \\
\hline
\end{tabular}

5-FU: fluorouracil

Table 2. American Joint Committee on Cancer 8th edition staging system for pancreatic cancer

\begin{tabular}{|c|c|c|c|c|}
\hline Primary tumor (T) & \multicolumn{3}{|c|}{ Regional lymph node (N) } & Distant metastase (M) \\
\hline $\begin{array}{l}\text { T1 Maximum tumor diameter } \leq 2 \mathrm{~cm} \\
\text { T2 Maximum tumor diameter }>2 \mathrm{~cm} \text { but } \leq 4 \mathrm{~cm} \\
\text { T3 Maximum tumor diameter }>4 \mathrm{~cm} \\
\text { T4 Tumor involves the celiac axis or the superior } \\
\text { mesenteric artery (unresectable primary tumor) }\end{array}$ & \multicolumn{3}{|c|}{$\begin{array}{l}\text { N1 Metastasis in } 1-3 \text { regional lymph nodes } \\
\text { N2 Metastasis in } \geq 4 \text { regional lymph nodes }\end{array}$} & $\begin{array}{l}\text { MO No distant metastasis } \\
\text { M1 Distant metastasis }\end{array}$ \\
\hline \multicolumn{5}{|l|}{ Stage } \\
\hline Stage $1 \mathrm{~A}$ & $\mathrm{~T} 1$ & NO & MO & \\
\hline Stage 1B & $\mathrm{T} 2$ & NO & MO & \\
\hline Stage $2 \mathrm{~A}$ & T3 & NO & MO & \\
\hline Stage 2B & $\mathrm{T} 1-3$ & N1 & MO & \\
\hline Stage 3 & Any $T$ & N2 & MO & \\
\hline & T4 & Any $\mathrm{N}$ & & \\
\hline Stage 4 & Any $T$ & Any N & M1 & \\
\hline
\end{tabular}

blood vessels is called resectable. Cancer that is confined to the pancreas but involves nearby blood vessels or structures to a greater extent is called borderline resectable ${ }^{[23]}$. Cancer that involves nearby blood vessels or other structures to such a significant extent that it cannot be successfully removed by surgery is called locally advanced nonresectable ${ }^{[24]}$. Cancer that has spread outside the pancreas to other organs and tissues in the body is called metastatic. Patients with metastatic disease are not indicated to have surgical resection ${ }^{[2]}$.

All patients must undergo preoperative exams such as contrast-enhanced abdominal computed tomography or magnetic resonance imaging with cholangiopancreaticography so the surgeons can decide what kind of procedure to apply on each patient.

For those patients that are possible to undergo resection there are three types of surgery: Whipple procedure, distal pancreatectomy, and total pancreatectomy. Conventional Whipple operation or pylorus preserving, also known as pancreaticodueodenectomy, with lymphadenectomy is the choice for head or neck pancreatic cancers. Distal pancreatectomy with splenectomy is the choice for body/tail cancer. The Whipple procedure removes the head of the pancreas, the gallbladder, duodenum, part of the bile duct, and often part of the stomach. It also removes the nearest lymph nodes to biopsy. The distal pancreactectomy removes the body and tail of the pancreas, some nearby lymph nodes, and sometimes the spleen and its blood vessels. The total pancreactectomy removes the gallbladder, duodenum, part of the bile duct and stomach, nearby lymph nodes, and sometimes the spleen ${ }^{[26-28]}$. The prognosis for patients that go through resection depends on 
margin status. The one associated with the best outcomes is a Ro resection which means a total gross excision and negative histological margins; R1 resection is a total gross excision however with positive histological margins; and, $\mathrm{R} 2$ is a resection with residual gross tumor and patients that undergo $\mathrm{R} 2$ resection have similar prognosis of the unresectable patients treated with non-operative therapy, on account of that, surgeries that will result in R2 margins should not be consider as resectable ${ }^{[23,29]}$.

To improve survival for locally advanced patients neoadjuvant therapy has been evaluated aiming to shrink tumor, enhance resectability and also to increase rates of microscopic complete tumor resection ${ }^{[30]}$.

\section{CHEMOTHERAPY GEMZAR - GEMCITABINE}

Gemcitabine is a deoxycytidine (dCTP) analogue, which is converted by nucleoside kinases into two metabolites diphosphate (dFdCDP) and triphosphate (dFdCTP). Each of these metabolites have a specific mechanism of action: (1) the diphosphate metabolite (dFdCDP) inhibits ribonuclease reductase, an enzyme known for catalyzing the reaction that generates ribonucleotides necessary for DNA synthesis; (2) the triphosphate metabolite (dFdCTP) competes with the natural dCTP for its incorporation into DNA newly synthetized strands. Once dFdCTP is incorporated, only one additional nucleotide is added to the growing DNA strands, which stops the DNA synthesis and eventually results in activation of apoptosis pathway leading the cells to death ${ }^{[31]}$.

Gemcitabine, as single-agent, became the first line treatment (1996) for advanced pancreatic cancer since a randomized trial showing that $23.8 \%$ of patients had experienced a clinical benefit response compared with $4.8 \%$ of patients treated with fluorouracil (5-FU). Gemcitabine also confers a modest improvement in overall survival than those observed in patients group treated with 5-FU. The patients' overall survival rates at 12 months were $18 \%$ for gemcitabine and $2 \%$ for patients treated with $5-\mathrm{FU}^{[32]}$.

In the following decade, gemcitabine has become the backbone of combination regimen for new experimental approaches with either other cytotoxic molecules or novel chemotherapy agents ${ }^{[33]}$. Many phase II trials have demonstrated the efficacy of gemcitabine-based combinations, which comprise other cytotoxic molecules such as capecitabine, 5-FU, cisplatin, irinotecan ${ }^{[34-37]}$ or the targeted agents sorafenib and cetuximab ${ }^{[38-40]}$. However, in some randomized phase III trials of gemcitabine based chemotherapy combinations, these combinations failed to show statistically significant improvement in patient's overall survival when compared to gemcitabine used as a single-agent ${ }^{[11-46]}$.

Nowadays, gemcitabine is used in combination with taxol, a paclitaxel albumin-stabilized nanoparticle formulation (nab-paclitaxel) that is commercially known as abraxane. Taxol is a microtubule dynamics inhibitor that promotes the stabilization of microtubules by preventing the catastrophe process, which induces cell cycle arrest at the G2/M phase resulting in cell death ${ }^{[14]}$. In preclinical studies, nab-paclitaxel improved the intratumoral concentration of gemcitabine. The FDA approval for this approach was obtained after a phase III study that demonstrated the efficacy and safety of this combination compared to monotherapy with gemcitabine in patients with metastatic pancreatic cancer. Von Hoff et al ${ }^{[47]}$, randomized assigned 861 patients: 431 received nab-paclitaxel plus gemcitabine and 430 gemcitabine alone. The median overall survival was 1.8 months superior in the combination group, and the survival rate was $35 \%$ in the nab-paclitaxel-gemcitabine group compared to $22 \%$ in the gemcitabine group in 1 year. Moreover, this combination approach increased the median progression-free survival in 1.8 months. However, despite those benefits rates, peripheral neuropathy and myelosuppression were increased in the group that received nabpaclitaxel-gemcitabine combination ${ }^{[47]}$. De vita et al. ${ }^{[48]}$ also confirmed the effectiveness in overall survival and progression free survival from patients treated with the combination of gemcitabine plus nabpaclitaxel.

Although not yet approved by the FDA as a treatment approach for pancreatic cancer, the ESPAC-4 study developed a phase III randomized trial that could establish the gemcitabine plus capecitabine combination 
as the treatment of choice for adjuvant setting after resection ${ }^{[49]}$. In this study, they aimed to demonstrate the safety and efficacy of the combination for resected pancreatic cancer since a phase III randomized comparison between gemcitabine plus capecitabine and gemcitabine alone showed a significant improvement in objective response rate $(P=0.03)$ and progression-free survival $(P=0.004)$ and was associated with a trend toward improved overall survival $(P=0.08)$ in patients with advanced pancreatic cancer that underwent the combination approach ${ }^{[50]}$. The capecitabine is an oral prodrug of $5-\mathrm{FU}$, a fluoropyrimidine carbamate, that provides prolonged fluorouracil tumor exposure at lower peak concentration. The conversion of capecitabine in the active drug needs an enzyme named thymidine phosphorylase which is present at higher levels in tumor cells compared to other tissues which improves tolerability and intratumor drug concentration ${ }^{[51]}$.

\section{FOLFIRINOX REGIMEN - FLUOROURACIL, LEUCOVORIN, IRINOTECAN AND OXALIPLATIN}

5-FU is a fluoropyrimidine antimetabolite drug that exerts antitumoral effects inhibiting the enzyme thymidylate synthase, impairing the synthesis of the pyrimidine thymine, which is required for genetic material synthesis. The fluoronucleotides are misincorporated into RNA and DNA strands resulting in cell death ${ }^{[52]}$. Leucovorin is a metabolite of folinic acid, known as 5 -formyltetrahydrofolic acid, which is the 5 -formyl derivative of tetrahydrofolic acid ${ }^{[53]}$. Leucovorin is indicated for use as rescue therapy to reduce the toxicity associated of folinic acid antagonists that inhibits de novo synthesis of purines, pyrimidines and methionine. The combination of leucovorin and 5-FU can extend the survival in the palliative treatment of patients with advanced pancreatic cancer ${ }^{[54,55]}$. Irinotecan is a derivative of camptothecin that has a cytotoxic action via a potent and specific inhibition of DNA topoisomerase I, preventing the DNA strand ligation leading to double-strand DNA breakage and cell death ${ }^{[56]}$. Oxaliplatin is a platinum-based drug that belongs to the same family of cisplatin and carboplatin. In oxaliplatin the two amine groups were replaced by cyclohexyldiamine, which increases its antitumor effect. The chlorine ligands were replaced by the oxalato bidentate derived from oxalic acid that improves its water solubility ${ }^{[57,58]}$. Oxaliplatin is converted to active derivatives via displacement of the labile oxalate ligand. Its reactive species monoaquo and diaquo diaminocyclohexane platinum binds guanine and cytosine moieties of DNA and this association produces cross-linking of DNA inhibiting the DNA synthesis and transcription ${ }^{[59]}$.

A phase 1 study involving patients with advanced solid tumor was developed to determine the maximumtolerated dose and the recommended dose of the triple combination (oxaliplatin, irinotecan, leucovorin/5-FU). A fair response in patients with advanced pancreatic cancer utilizing this combining regimen was observed ${ }^{[60]}$. Then, a phase 2 study of FOLFIRINOX regimen was conducted involving 46 advanced pancreatic cancer patients with good performance status. FOLFIRINOX showed a high efficacy against this malignant tumor, but it has produced severe neutropenia in half of the patients. It was prompted started the phase 2-3 trial in order to compare FOLFIRINOX regimen with gemcitabine as single antitumoral agent. In this trial, 342 patients were randomly assigned. The median overall survival and the median progressionfree survival were significantly extended for the FOLFIRINOX regimen group (48\% of patients submitted to FOLFIRINOX regimen were alive after 1 year compared to $20 \%$ treated with gemcitabine). Due to its high toxicity, the group treated with FOLFIRINOX showed more intense side effects such as grade 3 or 4 neutropenia, thrombocytopenia and grade 2 alopecia. However, despite the higher incidence of intense side effects, the FOLFIRINOX treated group showed a significant increase of time period that precedes the definitive deterioration of the quality of life compared to gemcitabine group. These results lead to the conclusion that FOLFIRINOX is an effective therapeutic option but only suitable for patients with metastatic pancreatic cancer that hold a good performance status ${ }^{[6] 1}$.

After the effectiveness of FOLFIRINOX regimen in the palliative setting has been established, Faris et al. ${ }^{[62]}$ had performed a retrospective study in the Massachusetts General Hospital Cancer Center to answer two questions that remained unclear: will the benefit in response rate and overall survival in the metastatic setting translate to patients with locally advanced pancreatic cancer? And are curative-intent resections 
possible in patients who respond to this treatment? They found that FOLFIRINOX regimen have substantial activity in locally advanced pancreatic cancer patients and also, that the use of FOLFIRINOX regimen could induce cancer conversion to resectability in more than $20 \%$ of patients. From those patients that could resect the cancer, 3 from 5 had recurrence and $1 / 3$ of patients had experienced significant toxicity signals that required visits to emergency department or hospitalization. The most prevalent effects were anemia grade 1 or 2 , thrombocytopenia (mostly grade 1), neutropenia, diarrhea/dehydration. Due to high toxicity of FOLFIRINOX regimen, further studies were suggested to reach an optimized treatment to patients with locally advanced pancreatic cancer.

In the other hand, FOLFIRINOX has been studied as neoadjuvant option for locally advanced and borderline resectable patients ${ }^{[63-65]}$. The neoadjuvant therapy can benefit by converting a few locally advanced tumors into resectable ones and increase Ro resectability in borderline tumors ${ }^{[6,67]}$. The FOLFIRINOX combination regime was associated with an increase in Ro resection rates when administered with or without radiotherapy before surgery in borderline resectable and locally advanced patients. The most important result is the down staging of the disease in locally advanced, thus making it possible for patients to undergo surgery and increasing the median progression free survival ${ }^{[19,68,69]}$. However, phase III studies should be prompted to confirm whether preoperative neoadjuvant $v s$. postoperative adjuvant treatment relates to better survival for those patients that can undergo surgery ${ }^{[70]}$.

\section{ONYVIDE - NANOLIPOSOMAL IRINOTECAN, 5-FU AND FOLINIC ACID}

Nanoliposomal irinotecan has potential antineoplastic activity; its liposome encapsulation promotes better delivery of drugs into the cytosol from the endosome compartment of the cell. This encapsulation platform of drug delivery reduces the premature systemic drug release but maintains its intra tumoral release, enhancing antitumor activity ${ }^{[71]}$.

On October 22, 2015, the U.S. FDA has approved the onivyde (irinotecan liposome injection) in combination with 5-FU and leucovorin to treat patients with advanced metastatic pancreatic cancer who have been previously treated with gemcitabine-based chemotherapy. The approval was due to a phase III study, conducted after preceding trials showing promising activity of the nanoliposomal irinotecan in patients with metastatic pancreatic ductal adenocarcinoma previously treated with gemcitabine $e^{[72]}$.

In the phase III trial, nanoliposomal irinotecan was tested alone or in combination with 5-FU and folinic acid, compared with a common control (5-FU and folinic acid) in patients with metastatic pancreatic cancer progression after a regimen of gemcitabine. It was a global, randomized, open-label trial in 14 countries. Their results showed that nanoliposomal irinotecan plus 5-FU and folinic acid significantly improved the overall survival. Also, the results related with progression-free survival, objective tumor response, time to treatment failure and CA19-9 tumor marker response for those patients were significantly improved in contrast to the 5-FU and folinic acid control group. Neutropenia, fatigue, diarrhea and regurgitating were the main side effects observed in patients group $(14.5 \%, 13.7 \%, 12.8 \%, 11.1 \%$ respectively) submitted to treatment with the combination of nanoliposomal irinotecan with 5-FU and folinic acid. With a manageable safety profile, this approach represents a new treatment option for many patients with metastatic pancreatic cancer that previously received an unsuccessful gemcitabine therapy ${ }^{[73]}$.

There is an ongoing trial, randomized, open-label, phase II study of onivyde $v s$. nab-paclitaxel + gemcitabine in patients with metastatic pancreatic adenocarcinoma (NCT02551991) ${ }^{[74]}$.

\section{IMMUNOTHERAPY}

Despite all chemotherapy combinations and new trials with targeted therapies, overall survival of advanced pancreatic cancer patients remains poor. The establishments of new therapies that provide long-term 
benefit are urgently needed. The spotlights are now on new immunotherapy approaches, since it is an unexplored and growing landscape and has been applied successfully in other types of cancer. There are many evidences showing that pancreatic cancer generates antitumor immune responses, suggesting that immunotherapies can be a promising alternative for those patients ${ }^{[75]}$. As already known, pancreatic cancer creates an immunosuppressive tumor microenvironment with mucin overexpression. To overcome this immunosuppressive microenvironment, Banerjee et al ${ }^{[76]}$ have developed a nanovaccine using recombinant fragments of MUC4, a highly expressed mucin which contributes to cancer aggressiveness, and immunized KPC mice. When compared to control group, the immunized mice exhibited a slower tumor growth kinetics and a greater accumulation of CD $8+$ and $\mathrm{CD} 4+\mathrm{T}$ cells. The suppression of tumor progression caused by the immunization points the MUC4 nanovaccine to be a potential immunotherapy for pancreatic cancer.

Another potential immunotherapy approach resulted from the study in which they administered AMD3100 (plerixafor) in KPC mice. AMD3100 is an inhibitor of chemokine receptor CXCR4, a CXCL12 receptor. The inhibition of CXCR4 by the AMD3100 contributes to a fast T cell accumulation in regions of the tumor and acted together with the immunological checkpoint antagonist, $\alpha$-programmed cell death 1 ligand 1 , to reduce cancer cells $s^{[77]}$.

Five main categories for immunotherapy applied to pancreatic cancer have been described ${ }^{[78]}$ : (1) checkpoint inhibitors/immune modulators. This strategy aims to modulate immune system through inhibitory or stimulatory signals, such as inhibition of $\mathrm{CD} 28$ family receptors, which controls T cell responses, modulating the immune cytotoxic response, restoring or increasing the cytotoxic antitumor activities of $\mathrm{T}$ cell ${ }^{[79]}$; (2) therapeutic vaccines. In these cases, occurs a patient's active immunization with tumor specific antigen. This vaccine will trigger $\mathrm{T}$ cells and increase its activity against the tumor ${ }^{[80]}$; (3) adoptive $\mathrm{T}$ cell transfer. An adoptive $\mathrm{T}$ cell transfer is a kind of transfusion therapy that infuses mature $\mathrm{T} C \mathrm{CD} 8+$ specific cells in patients. These cells target surface proteins in tumor tissue, which are used to T CD8+ cells docking and eliminate cancer cells through granzyme and perforin $\operatorname{secretion}^{[81]}$; (4) monoclonal antibodies. This approach is a passive immunization using antibodies against the same cancer molecule epitope, created to target specific tumor antigens, which enhance the cancer cells recognition by phagocytes and T CD8+ cells improving its elimination; (5) cytokines use. The cytokines such as IL-10 and IL-17B are used to regulate tumor microenvironment, aiming to suppress the cancer cells property to express immunosuppressive cytokines that stop the immune activation against the cancer cells ${ }^{[78]}$.

Even though many encouraging results have been obtained for other types of cancer $^{[82-84]}$, none of these treatments showed significant efficiency when applied as pancreatic cancer therapy ${ }^{[85,86]}$. Currently, although there are many ongoing trials for immunotherapy, therapeutic vaccines are the most cutting-edge clinical therapy applied as pancreatic cancer immunotherapy. Concerning to vaccines as immunotherapy category, the most advanced studies to date are those conducted with whole-cell vaccines and granulocyte-macrophage colony-stimulating factor (GM-CSF) vaccines.

\section{THERAPEUTIC VACCINE IMMUNOTHERAPY WHOLE-CELL VACCINES}

Algenpantucel - $\mathrm{L}$ is an irradiated, live combination of two human allogeneic pancreatic cell lines that express the murine enzyme $\alpha$-1,3-galactosyl transferase. This enzyme performs the addition of $\alpha$-galactosyl epitopes on surface proteins and glycolipids of such cell lines. The human cells do not express murine alphagal epitopes and these cells inoculation induce a hyperacute rejection of the vaccine pancreatic allograft cell. The hyperacute rejection results in the fast activation of antibody-dependent cell-mediate cytotoxicity. These processes will also stimulate the host immune system to eliminate endogenous pancreatic cancer cells ${ }^{[78,87]}$. Hardacre et al.$^{[88]}$ in 2013 performed a multi-institutional, open-label phase II trial to evaluate the use of algenpantucel-L in addition to standard adjuvant chemotherapy and chemoradiotherapy setting for resected pancreatic cancer patients (NCT00569387). In this study 70 patients were treated with gemcitabine 
Table 3. Therapeutic vaccines immunotherapy summary

\begin{tabular}{llllll}
\hline & Clinical trial & Biological & Intervention & Phase & Patient \\
\hline Whole cell & NCT01072981 & Algenpantucel-L & + Gemcitabine & III ongoing & Resected pancreatic cancer \\
vaccines & NCT01303172 & IMM-101 & + Gemcitabine & II completed & Advanced pancreatic cancer \\
GM-CSF vaccines & & GVAX + CR207 & Cy/GVAX + CRS207 & II completed & Metastatic pancreatic cancer \\
\hline
\end{tabular}

GM-CSF: granulocyte-macrophage colony-stimulating factor; Cy: cyclophosphamide

and 5-FU based chemoradiotherapy as well as algenpantucel-L. The median follow-up was 21 months, and the one-year progression-free survival was $62 \%$ added to an $86 \%$ overall survival. Inoculation site pain and local tissue induration were the common side events; however, the allogenic cells administration was safe, and it proves to be a feasible combined approach. The results obtained from this phase II trial demonstrated that this immunotherapy component may improve survival, and due to such optimistical results a multiinstitutional phase III study is ongoing (NCT01072981).

Another randomized phase II trial explored the safety and tolerability of an injectable immunomodulator from heat-killed mycobacterium obuense (IMM-101) used in combination with gemcitabine. This study showed that the administration of IMM-101 plus gemcitabine was safe and well tolerated as gemcitabine alone in patients with advanced pancreatic cancer, moreover the results from this phase II trial suggested a beneficial effect on overall survival which may support further evaluation of IMM-101 in a confirmatory study ${ }^{[89]}$.

\section{GM-CSF VACCINES}

A recent phase II randomized multicenter study was conducted comparing cyclophosphamide (Cy)/GVAX followed by CRS-207 with Cy/GVAX alone in patients with metastatic pancreatic cancer. Cy/GVAX is composed of two irradiated GM-CSF-secreting allogeneic pancreatic cancer cell lines administered with low-dose of Cy to hinder regulatory T cells. GVAX induces T CD8+ cells activity against a tumor associated antigen named mesothelin that is over expressed in most pancreatic cancer cells. CRS-207 is a live-attenuated Listeria monocytogene-gene expressing mesothelin that induces innate and adaptative immunity response. The overall survival for the Cy-GVAX followed by CRS-207 was 6.1 months compared to 3.9 months of CyGVAX alone. Stable disease rate of $31 \%$ and 1-year survival rate of $24 \%$ are encouraging results. Furthermore, heterologous boost with Cy-GVAX and CRS-207 extended overall survival for pancreatic cancer patients with minimal related toxicities ${ }^{[90]}$ [Table 3].

Worldwide efforts should be directed to identification and selection of specific antigens in order to induce immune response against pancreatic cancer cells aiming to eliminate the immunosuppressive microenvironment that this cancer produces. Appropriate selection of target antigens and combination of treatment protocols are critical to enhance treatment efficacy, lowering related toxicities and as already demonstrated improving the overall survival ${ }^{[91]}$.

Regardless of the advances in pancreatic tumor biology knowledgment, mechanisms associated with the tumor microenvironment remain poorly understood, highlighting that the distinct composition of pancreatic tumor microenvironment could be a great barrier for immunotherapy success ${ }^{[92]}$. As a consequence of newly emerging information about tumor microenvironment, there was a shift in the cancer development concept from a tumor cell-centered view to a complex tumor ecosystem, which led to the acceptance that cancer cells interact with the extracellular matrix (ECM) and stromal cells ${ }^{[93,94]}$. A major component of the extracellular matrix is hyaluronic acid (HA), a hydrophilic glycosaminoglycan that is produced in bulk by many pancreatic cancer. Accumulation of HA in tumors is associated with malignancy and poor prognosis, because HA polymers bind and trap water molecules in the ECM as a fluid gel that increases interstitial fluid pressure and creates a physical barrier that restricts antibody and immune cells access the tumor. A pegylated recombinant human hyaluronidase (PEGPH20) is an agent that degrades the hyaluronic acid and normalizes interstitial 
fluid pressure and has been applied to enhance the delivery of cytotoxic drugs ${ }^{[95]}$. Hingorani et al. ${ }^{[96]}$ showed the results from a phase II comparison study between PEGPH20 [plus nab-paclitaxel/gemcitabine (AG)] (PAG) vs. AG in patients with untreated metastatic pancreatic ductal adenocarcinoma (NCT01839487). Because of an imbalance in thromboembolic events in PAG patients $40 \%$ patients were excluded from the study. In order to conclude this trial, the enoxaparin prophylaxis was applied in both arms and the phase II study comparison was successful. This randomized phase II met both primary endpoints (progression-free survival and thromboembolic event rate), with the greater improvement in the secondary endpoint which is the progression-free survival in HA-high patients. In the subset of 80 patients whose tumors had HAhigh levels, the addition of PEGPH20 to chemotherapy resulted in an increase of 4 months of stable clinic conditions before disease progression when compared to chemotherapy alone. The results of the phase II trial suggested that HA has a potential predictive biomarker for patient's selection of PEGPH20, qualifying only patients with high levels of HA for the new phase III trial. The ongoing phase III trial (NCT02715804) intends to determine whether PEGPH20 actually increases patients' overall survival and not just their time to disease progression.

\section{RADIOTHERAPY}

The effectiveness of radiotherapy has been continuously debated ${ }^{[97-99]}$. Recent studies have shown that the addition of radiotherapy to chemotherapy in the setting of locally advanced pancreatic cancer did not improve overall survival outcome ${ }^{[100,101]}$. A recent randomized phase III trial, LAP07 (NCT00634725) compared chemoradiotherapy in patients with locally advanced pancreatic cancer controlled after 4 months of gemcitabine-based chemotherapy with chemotherapy alone. No significant difference in overall survival was found. However, an increase in progression-free survival resulted in a longer period without treatment confirming association of chemoradiotherapy with decreased local progression ${ }^{[102]}$. Other studies have proposed that chemotherapy administered before simultaneous chemoradiotherapy could enhance survival $^{[103,104]}$. Therefore, the benefits of radiation therapy in the management of locally advanced pancreatic cancer remain controversial .

\section{CONCLUSION}

Although some studies had demonstrated a mild increase in survival rates, there are no available treatments to pancreatic cancer that are focused on preserving the patients' quality of life.

Considering this deadly disease, it is time to take into account the balance between overall survival and patient's life quality. Pancreatic cancer patients desperately need more specific drugs or drugs combinations capable of eliminating cancer cells without producing so many toxic effects. The real cost for one or two more months of life, is living in pain with severe diarrhea, vomits, neutropenia and immune deficiency.

The lack of an efficient therapy against pancreatic cancer has turned the spotlights to immunotherapy. Despite of many disappointments in several clinical trials, immunotherapy has become an established modality for treatment of other cancer types such as melanoma, breast and lung cancer. Clinical trials testing anticancer vaccines showed promising results to treat pancreatic cancer, however most of them have failed to demonstrate a significant efficacy in improving patient's overall survival and quality of life.

As already discussed, a more comprehensive understanding of cancer microenvironment and the chemical communication between cancer cells and immune cells can result in new molecules targets and pathways, which could be used to increase the immune responses against tumoral cells. These hypothetical targets may ultimately lead, alone or combined with a proper chemotherapy scheme, to a massive cancer cells elimination, improving quality of life and significantly extending overall survive of patients. 


\section{DECLARATIONS}

\section{Authors' contributions}

Searched bibliographic references data: Pereira NP, Corrêa JR

Edited partial scientific text: Pereira NP, Corrêa JR

Reviewed scientific text: Corrêa JR

\section{Availability of data and materials}

Not applicable.

\section{Financial support and sponsorship}

None.

\section{Conflicts of interest}

Both authors declare no conflicts of interest in association with this study.

\section{Ethical approval and consent to participate}

Not applicable.

\section{Consent for publication}

Not applicable.

\section{Copyright}

(c) The Author(s) 2018.

\section{REFERENCES}

1. Siegel RL, Miller KD, Jemal A. Cancer statistics, 2018. CA Cancer J Clin 2018;68:7-30.

2. Hidalgo M. Pancreatic cancer. N Engl J Med 2010;362:1605-17.

3. Goel G, Sun W. Novel approaches in the management of pancreatic ductal adenocarcinoma: potential promises for the future. J Hematol Oncol 2015;8:44.

4. Karanikas M, Esempidis A, Chasan ZT, Deftereou T, Antonopoulou M, Bozali F, Amarantidis K, Man YG. Pancreatic cancer from molecular pathways to treatment opinion. J Cancer 2016;7:1328-39.

5. Soo RA, Yong WP, Innocenti F. Systemic therapies for pancreatic cancer-the role of pharmacogenetics. Curr Drug Targets 2012;13:811-28.

6. Ferlay J, Soerjomataram I, Dikshit R, Eser S, Mathers C, Rebelo M, Parkin DM, Forman D, Bray F. Cancer incidence and mortality worldwide: sources, methods and major patterns in GLOBOCAN 2012. Int J Cancer 2015;136:E359-86.

7. Bosetti C, Rosato V, Li D, Silverman D, Petersen GM, Bracci PM, Neale RE, Muscat J, Anderson K, Gallinger S, Olson SH, Miller AB, Bas Bueno-de-Mesquita H, Scelo G, Janout V, Holcatova I, Lagiou P, Serraino D, Lucenteforte E, Fabianova E, Ghadirian P, Baghurst PA, Zatonski W, Foretova L, Fontham E, Bamlet WR, Holly EA, Negri E, Hassan M, Prizment A, Cotterchio M, Cleary S, Kurtz RC, Maisonneuve P, Trichopoulos D, Polesel J, Duell EJ, Boffetta P, La Vecchia C. Diabetes, antidiabetic medications, and pancreatic cancer risk: an analysis from the International Pancreatic Cancer Case-Control Consortium. Ann Oncol 2014;25:2065-72.

8. Sah RP, Nagpal SJ, Mukhopadhyay D, Chari ST. New insights into pancreatic cancer-induced paraneoplastic diabetes. Nat Rev Gastroenterol Hepatol 2013;10:423-33.

9. Hamilton SR, Aanltonen LA. World Health Organization Classification of Tumours. Pathology and genetics of tumours of the digestive system. IARC Press 2000.

10. Raimondi S, Lowenfels AB, Morselli-Labate AM, Maisonneuve P, Pezzilli R. Pancreatic cancer in chronic pancreatitis; aetiology, incidence, and early detection. Best Pract Res Clin Gastroenterol 2010;24:349-58.

11. Hruban RH, Canto MI, Goggins M, Schulick R, Klein AP. Update on familial pancreatic cancer. Adv Surg 2010;44:293-311.

12. Wolfgang CL, Herman JM, Laheru DA, Klein AP, Erdek MA, Fishman EK, Hruban RH. Recent progress in pancreatic cancer. CA Cancer J Clin 2013;63:318-48.

13. Iodice S, Gandini S, Maisonneuve P, Lowenfels AB. Tobacco and the risk of pancreatic cancer: a review and meta-analysis. Langenbecks Arch Surg 2008;393:535-45.

14. Chiorean EG, Coveler AL. Pancreatic cancer: optimizing treatment options, new, and emerging targeted therapies. Drug Des Devel Ther 2015;9:3529-45.

15. Lee SY, Sissoko M, Hartshorn KL. Update on the management of pancreatic cancer in older adults. Curr Oncol Rep 2016;18:60. 
16. Kosmidis C, Sapalidis K, Kotidis E, Mixalopoulos N, Zarogoulidis P, Tsavlis D, Baka S, Man YG, Kanellos J. Pancreatic cancer from bench to bedside: molecular pathways and treatment options. Ann Transl Med 2016;4:165.

17. Silverman DT, Schiffman M, Everhart J, Goldstein A, Lillemoe KD, Swanson GM, Schwartz AG, Brown LM, Greenberg RS, Schoenberg JB, Pottern LM, Hoover RN, Fraumeni JF Jr. Diabetes mellitus, other medical conditions and familial history of cancer as risk factors for pancreatic cancer. Br J Cancer 1999;80:1830-7.

18. Kamarajah SK, Burns WR, Frankel TL, Cho CS, Nathan H. Validation of the American Joint Commission on Cancer (AJCC) 8th edition staging system for patients with pancreatic adenocarcinoma: a surveillance, epidemiology and end results (SEER) analysis. Ann Surg Oncol 2017;24:2023-30.

19. Silvestris N, Longo V, Cellini F, Reni M, Bittoni A, Cataldo I, Partelli S, Falconi M, Scarpa A, Brunetti O, Lorusso V, Santini D, Morganti A, Valentini V, Cascinu S. Neoadjuvant multimodal treatment of pancreatic ductal adenocarcinoma. Crit Rev Oncol Hematol 2016;98:309-24.

20. Siegel RL, Miller KD, Jemal A. Cancer statistics, 2016. CA Cancer J Clin 2016;66:7-30.

21. Cancer Facts \& Figures 2017. American Cancer Society 2017.

22. McIntyre CA, Winter JM. Diagnostic evaluation and staging of pancreatic ductal adenocarcinoma. Semin Oncol 2015;42:19-27.

23. Lopez NE, Prendergast C, Lowy AM. Borderline resectable pancreatic cancer: definitions and management. World J Gastroenterol 2014;20:10740-51.

24. Shaib WL, Ip A, Cardona K, Alese OB, Maithel SK, Kooby D, Landry J, El-Rayes BF. Contemporary management of borderline resectable and locally advanced unresectable pancreatic cancer. Oncologist 2016;21:178-87.

25. Buanes TA. Role of surgery in pancreatic cancer. World J Gastroenterol 2017;23:3765-70.

26. Kleeff J, Diener MK, Z’Graggen K, Hinz U, Wagner M, Bachmann J, Zehetner J, Müller MW, Friess H, Büchler MW. Distal pancreatectomy: risk factors for surgical failure in 302 consecutive cases. Ann Surg 2007;245:573-82.

27. Ho CK, Kleeff J, Friess H, Buchler MW. Complications of pancreatic surgery. HPB (Oxford) 2005;7:99-108.

28. Kim CB, Ahmed S, Hsueh EC. Current surgical management of pancreatic cancer. J Gastrointest Oncol 2011;2:126-35.

29. Bachmann J, Michalski CW, Martignoni ME, Buchler MW, Friess H. Pancreatic resection for pancreatic cancer. HPB (Oxford) 2006;8:346-51.

30. Kircher SM, Krantz SB, Nimeiri HS, Mulcahy MF, Munshi HG, Benson AB 3rd. Therapy of locally advanced pancreatic adenocarcinoma: unresectable and borderline patients. Expert Rev Anticancer Ther 2011;11:1555-65.

31. Cerqueira NM, Fernandes PA, Ramos MJ. Understanding ribonucleotide reductase inactivation by gemcitabine. Chemistry 2007;13:8507-15.

32. Burris HA 3rd MM, Andersen J, Green MR, Rothenberg ML, Modiano MR, Cripps MC, Portenoy RK, Storniolo AM, Tarassoff P, Nelson R, Dorr FA, Stephens CD, Von Hoff DD. Improvements in survival and clinical benefit with gemcitabine as first-line therapy for patients with advanced pancreas cancer: a randomized trial. J Clin Oncol 1997;15:2403-13.

33. Kim EJ, Semrad TJ, Bold RJ. Phase II clinical trials on investigational drugs for the treatment of pancreatic cancers. Expert Opin Investig Drugs 2015;24:781-94.

34. Scheithauer W. Biweekly high-dose gemcitabine alone or in combination with capecitabine in patients with metastatic pancreatic adenocarcinoma: a randomized phase II trial. Ann Oncol 2003;14:97-104.

35. Berlin JD, Adak S, Vaughn DJ, Flinker D, Blaszkowsky L, Harris JE, Benson IIIAB. A phase II study of gemcitabine and 5 fluorouracil in metastatic pancreatic cancer: an eastern cooperative oncology group study (E3296). Oncology 2000;58:215-8.

36. Philip PA, Zalupski MM, Vaitkevicius VK, Arlauskas P, Chaplen R, Heilbrun LK, Adsay V, Weaver D, Shields AF. Phase II study of gemcitabine and cisplatin in the treatment of patients with advanced pancreatic carcinoma. Cancer 2001;92:569-77.

37. Stathopoulos GP. Treatment of pancreatic cancer with a combination of irinotecan (CPT-11) and gemcitabine: a multicenter phase II study by the Greek cooperative group for pancreatic cancer. Ann Oncol 2003;14:388-94.

38. Di Marco M, Di Cicilia R, Macchini M, Nobili E, Vecchiarelli S, Brandi G, Biasco G. Metastatic pancreatic cancer: Is gemcitabine still the best standard treatment? (Review). Oncol Rep 2010;23:1183-92.

39. Kindler HL, Wroblewski K, Wallace JA, Hall MJ, Locker G, Nattam S, Agamah E, Stadler WM, Vokes EE. Gemcitabine plus sorafenib in patients with advanced pancreatic cancer: a phase II trial of the University of Chicago phase II consortium. Invest New Drugs 2012;30:382-6.

40. Xiong HQ, Rosenberg A, LoBuglio A, Schmidt W, Wolff RA, Deutsch J, Needle M, Abbruzzese JL. Cetuximab, a monoclonal antibody targeting the epidermal growth factor receptor, in combination with gemcitabine for advanced pancreatic cancer: a multicenter phase II trial. J Clin Oncol 2004;22:2610-6.

41. Berlin JD, Catalano P, Thomas JP, Kugler JW, Haller DG, Benson AB 3rd. Phase III study of gemcitabine in combination with fluorouracil versus gemcitabine alone in patients with advanced pancreatic carcinoma: eastern cooperative oncology group trial E2297. J Clin Oncol 2002;20:3270-5.

42. Stathopoulos GP, Syrigos K, Aravantinos G, Polyzos A, Papakotoulas P, Fountzilas G, Potamianou A, Ziras N, Boukovinas J, Varthalitis J, Androulakis N, Kotsakis A, Samonis G, Georgoulias V. A multicenter phase III trial comparing irinotecan-gemcitabine (IG) with gemcitabine $(\mathrm{G})$ monotherapy as first-line treatment in patients with locally advanced or metastatic pancreatic cancer. $\mathrm{Br} \mathrm{J}$ Cancer 2006;95:587-92.

43. Heinemann V, Quietzsch D, Gieseler F, Gonnermann M, Schönekäs H, Rost A, Neuhaus H, Haag C, Clemens M, Heinrich B, VehlingKaiser U, Fuchs M, Fleckenstein D, Gesierich W, Uthgenannt D, Einsele H, Holstege A, Hinke A, Schalhorn A, Wilkowski R. Randomized phase III trial of gemcitabine plus cisplatin compared with gemcitabine alone in advanced pancreatic cancer. J Clin Oncol 2006;24:3946-52. 
44. Louvet C, Labianca R, Hammel P, Lledo G, Zampino MG, André T, Zaniboni A, Ducreux M, Aitini E, Taïeb J, Faroux R, Lepere C, de Gramont A; GERCOR; GISCAD. Gemcitabine in combination with oxaliplatin compared with gemcitabine alone in locally advanced or metastatic pancreatic cancer: results of a GERCOR and GISCAD phase III trial. J Clin Oncol 2005;23:3509-16.

45. Kindler HL, Niedzwiecki D, Hollis D, Sutherland S, Schrag D, Hurwitz H, Innocenti F, Mulcahy MF, O’Reilly E, Wozniak TF, Picus J, Bhargava P, Mayer RJ, Schilsky RL, Goldberg RM. Gemcitabine plus bevacizumab compared with gemcitabine plus placebo in patients with advanced pancreatic cancer: phase III trial of the Cancer and Leukemia Group B (CALGB 80303). J Clin Oncol 2010;28:3617-22.

46. Philip PA, Benedetti J, Fenoglio-Preiser C, Zalupski M, Lenz H, O'Reilly E, Wong R, Atkins J, Abruzzese J, Blanke C. Phase III study of gemcitabine [G] plus cetuximab [C] versus gemcitabine in patients [pts] with locally advanced or metastatic pancreatic adenocarcinoma [PC]: SWOG S0205 study. J Clin Oncol 2007;25.

47. Von Hoff DD, Ervin T, Arena FP, Chiorean EG, Infante J, Moore M, Seay T, Tjulandin SA, Ma WW, Saleh MN, Harris M, Reni M, Dowden S, Laheru D, Bahary N, Ramanathan RK, Tabernero J, Hidalgo M, Goldstein D, Van Cutsem E, Wei X, Iglesias J, Renschler MF. Increased survival in pancreatic cancer with nab-paclitaxel plus gemcitabine. N Engl J Med 2013;369:1691-703.

48. De Vita F, Ventriglia J, Febbraro A, Laterza MM, Fabozzi A, Savastano B, Petrillo A, Diana A, Giordano G, Troiani T, Conzo G, Galizia G, Ciardiello F, Orditura M. NAB-paclitaxel and gemcitabine in metastatic pancreatic ductal adenocarcinoma (PDAC): from clinical trials to clinical practice. BMC Cancer 2016;16:709.

49. Neoptolemos JP, Palmer DH, Ghaneh P, Psarelli EE, Valle JW, Halloran CM, Faluyi O, O'Reilly DA, Cunningham D, Wadsley J, Darby S, Meyer T, Gillmore R, Anthoney A, Lind P, Glimelius B, Falk S, Izbicki JR, Middleton GW, Cummins S, Ross PJ, Wasan H, McDonald A, Crosby T, Ma YT, Patel K, Sherriff D, Soomal R, Borg D, Sothi S, Hammel P, Hackert T, Jackson R, Büchler MW; European study group for pancreatic cancer. Comparison of adjuvant gemcitabine and capecitabine with gemcitabine monotherapy in patients with resected pancreatic cancer (ESPAC-4): a multicentre, open-label, randomised, phase 3 trial. Lancet 2017;389:1011-24.

50. Cunningham D, Chau I, Stocken DD, Valle JW, Smith D, Steward W, Harper PG, Dunn J, Tudur-Smith C, West J, Falk S, Crellin A, Adab F, Thompson J, Leonard P, Ostrowski J, Eatock M, Scheithauer W, Herrmann R, Neoptolemos JP. Phase III randomized comparison of gemcitabine versus gemcitabine plus capecitabine in patients with advanced pancreatic cancer. J Clin Oncol 2009;27:5513-8.

51. Walko CM, Lindley C. Capecitabine: a review. Clin Ther 2005;27:23-44.

52. Longley DB, Harkin DP, Johnston PG. 5-fluorouracil: mechanisms of action and clinical strategies. Nat Rev Cancer 2003;3:330-8.

53. Stover P, Schirch V. The metabolic role of leucovorin. Trends Biochem Sci 1993;18:102-6.

54. Porcelli L, G. Assaraf Y, Azzariti A, Paradiso A, Jansen G, J. Peters G. The impact of folate status on the efficacy of colorectal cancer treatment. Curr Drug Metab 2011;12:975-84.

55. Danenberg PV, Gustavsson B, Johnston P, Lindberg P, Moser R, Odin E, Peters GJ, Petrelli N. Folates as adjuvants to anticancer agents: chemical rationale and mechanism of action. Crit Rev Oncol Hematol 2016;106:118-31.

56. Creemers GJ, Lund B, Verweij J. Topoisomerase I inhibitors: topotecan and irenotecan. Cancer Treat Rev 1994;20:73-96.

57. Tyagi P, Gahlot P, Kakkar R. Structural aspects of the anti-cancer drug oxaliplatin: a combined theoretical and experimental study. Polyhedron 2008;27:3567-74.

58. Faivre S, Chan D, Salinas R, Woynarowska B, Woynarowski JM. DNA strand breaks and apoptosis induced by oxaliplatin in cancer cells. Biochem Pharmacol 2003;66:225-37.

59. Arango D, Wilson AJ, Shi Q, Corner GA, Arañes MJ, Nicholas C, Lesser M, Mariadason JM, Augenlicht LH. Molecular mechanisms of action and prediction of response to oxaliplatin in colorectal cancer cells. Br J Cancer 2004;91:1931-46.

60. Ychou M. An open phase I study assessing the feasibility of the triple combination: oxaliplatin plus irinotecan plus leucovorin/5fluorouracil every 2 weeks in patients with advanced solid tumors. Ann Oncol 2003;14:481-9.

61. Conroy T, Desseigne F, Ychou M, Bouché O, Guimbaud R, Bécouarn Y, Adenis A, Raoul JL, Gourgou-Bourgade S, de la Fouchardière C, Bennouna J, Bachet JB, Khemissa-Akouz F, Péré-Vergé D, Delbaldo C, Assenat E, Chauffert B, Michel P, Montoto-Grillot C, Ducreux M; Groupe Tumeurs Digestives of Unicancer; PRODIGE Intergroup. FOLFIRINOX versus gemcitabine for metastatic pancreatic cancer. N Engl J Med 2011;364:1817-25.

62. Faris JE, Blaszkowsky LS, McDermott S, Guimaraes AR, Szymonifka J, Huynh MA, Ferrone CR, Wargo JA, Allen JN, Dias LE, Kwak EL, Lillemoe KD, Thayer SP, Murphy JE, Zhu AX, Sahani DV, Wo JY, Clark JW, Fernandez-del Castillo C, Ryan DP, Hong TS. FOLFIRINOX in locally advanced pancreatic cancer: the massachusetts general hospital cancer center experience. Oncologist 2013;18:543-8.

63. Christians KK, Tsai S, Mahmoud A, Ritch P, Thomas JP, Wiebe L, Kelly T, Erickson B, Wang H, Evans DB, George B. Neoadjuvant FOLFIRINOX for borderline resectable pancreas cancer: a new treatment paradigm? Oncologist 2014;19:266-74.

64. Palmarocchi MC, Balzarotti Canger RC, Saletti P. Neoadjuvant chemotherapy in borderline resectable pancreatic cancer: a case report. Oncol Lett 2017;13:4445-52.

65. Suker M, Beumer BR, Sadot E, Marthey L, Faris JE, Mellon EA, El-Rayes BF, Wang-Gillam A, Lacy J, Hosein PJ, Moorcraft SY, Conroy T, Hohla F, Allen P, Taieb J, Hong TS, Shridhar R, Chau I, van Eijck CH, Koerkamp BG. FOLFIRINOX for locally advanced pancreatic cancer: a systematic review and patient-level meta-analysis. Lancet Oncol 2016;17:801-10.

66. Conroy T, Bachet JB, Ayav A, Huguet F, Lambert A, Caramella C, Maréchal R, Van Laethem JL, Ducreux M. Current standards and new innovative approaches for treatment of pancreatic cancer. Eur J Cancer 2016;57:10-22.

67. Gillen S, Schuster T, Meyer Zum Buschenfelde C, Friess H, Kleeff J. Preoperative/neoadjuvant therapy in pancreatic cancer: a systematic review and meta-analysis of response and resection percentages. PLoS Med 2010;7:e1000267.

68. Hosein PJ, Macintyre J, Kawamura C, Maldonado JC, Ernani V, Loaiza-Bonilla A, Narayanan G, Ribeiro A, Portelance L, Merchan JR, Levi JU, Rocha-Lima CM. A retrospective study of neoadjuvant FOLFIRINOX in unresectable or borderline-resectable locally 
advanced pancreatic adenocarcinoma. BMC Cancer 2012;12:199.

69. Petrelli F, Coinu A, Borgonovo K, Cabiddu M, Ghilardi M, Lonati V, Aitini E, Barni S; Gruppo Italiano per lo Studio dei Carcinomi dell'Apparato Digerente (GISCAD). FOLFIRINOX-based neoadjuvant therapy in borderline resectable or unresectable pancreatic cancer: a metaanalytical review of published studies. Pancreas 2015;44:515-21.

70. Quiros RM, Brown KM, Hoffman JP. Neoadjuvant therapy in pancreatic cancer. Cancer Invest 2007;25:267-73.

71. Allen TM, Cullis PR. Drug delivery systems: entering the mainstream. Science 2004;303:1818-22.

72. Ur Rehman SS, Lim K, Wang-Gillam A. Nanoliposomal irinotecan plus fluorouracil and folinic acid: a new treatment option in metastatic pancreatic cancer. Expert Rev Anticancer Ther 2016;16:485-92.

73. Wang-Gillam A, Li C-P, Bodoky G, Dean A, Shan YS, Jameson G, Macarulla T, Lee KH, Cunningham D, Blanc JF, Hubner RA, Chiu CF, Schwartsmann G, Siveke JT, Braiteh F, Moyo V, Belanger B, Dhindsa N, Bayever E, Von Hoff DD, Chen LT; NAPOLI-1 Study Group. Nanoliposomal irinotecan with fluorouracil and folinic acid in metastatic pancreatic cancer after previous gemcitabine-based therapy (NAPOLI-1): a global, randomised, open-label, phase 3 trial. Lancet 2016;387:545-57.

74. Zhang H. Onivyde for the therapy of multiple solid tumors. Onco Targets Ther 2016;9:3001-7.

75. Amedei A, Niccolai E, Prisco D. Pancreatic cancer: role of the immune system in cancer progression and vaccine-based immunotherapy. Hum Vaccin Immunother 2014;10:3354-68.

76. Banerjee K, Gautam S, Nasser WM, Kshirsagar P, Ross K, Spagnol G, Aithal A, Sorgen P, Batra SK, Kumar S, Narasimhan B, Jain M. Abstract 3678: Muc4 nanovaccine and checkpoint blockade based combination immunotherapy for pancreatic cancer. Cancer Res 2017;77:3678.

77. Feig C, Jones JO, Kraman M, Wells RJ, Deonarine A, Chan DS, Connell CM, Roberts EW, Zhao Q, Caballero OL, Teichmann SA, Janowitz T, Jodrell DI, Tuveson DA, Fearon DT. Targeting CXCL12 from FAP-expressing carcinoma-associated fibroblasts synergizes with anti-PD-L1 immunotherapy in pancreatic cancer. Proc Natl Acad Sci U S A 2013;110:20212-7.

78. Kotteas E, Saif MW, Syrigos K. Immunotherapy for pancreatic cancer. J Cancer Res Clin Oncol 2016;142:1795-805.

79. Ito A, Kondo S, Tada K, Kitano S. Clinical development of immune checkpoint inhibitors. Biomed Res Int 2015;2015:605478.

80. Rosenberg SA, Yang JC, Restifo NP. Cancer immunotherapy: moving beyond current vaccines. Nat Med 2004;10:909-15.

81. June CH. Principles of adoptive T cell cancer therapy. J Clin Invest 2007;117:1204-12.

82. Robert C, Thomas L, Bondarenko I, O’Day S, Weber J, Garbe C, Lebbe C, Baurain JF, Testori A, Grob JJ, Davidson N, Richards J, Maio M, Hauschild A, Miller WH Jr, Gascon P, Lotem M, Harmankaya K, Ibrahim R, Francis S, Chen TT, Humphrey R, Hoos A, Wolchok JD. Ipilimumab plus dacarbazine for previously untreated metastatic melanoma. N Engl J Med 2011;364:2517-26.

83. Robert C, Schachter J, Long GV, Arance A, Grob JJ, Mortier L, Daud A, Carlino MS, McNeil C, Lotem M, Larkin J, Lorigan P, Neyns B, Blank CU, Hamid O, Mateus C, Shapira-Frommer R, Kosh M, Zhou H, Ibrahim N, Ebbinghaus S, Ribas A; KEYNOTE-006 investigators. Pembrolizumab versus ipilimumab in advanced melanoma. N Engl J Med 2015;372:2521-32.

84. Borghaei H, Paz-Ares L, Horn L, Spigel DR, Steins M, Ready NE, Chow LQ, Vokes EE, Felip E, Holgado E, Barlesi F, Kohlhäufl M, Arrieta O, Burgio MA, Fayette J, Lena H, Poddubskaya E, Gerber DE, Gettinger SN, Rudin CM, Rizvi N, Crinò L, Blumenschein GR Jr, Antonia SJ, Dorange C, Harbison CT, Graf Finckenstein F, Brahmer JR. Nivolumab versus docetaxel in advanced nonsquamous nonsmall-cell lung cancer. N Engl J Med 2015;373:1627-39.

85. Brahmer JR, Tykodi SS, Chow LQ, Hwu WJ, Topalian SL, Hwu P, Drake CG, Camacho LH, Kauh J, Odunsi K, Pitot HC, Hamid O, Bhatia S, Martins R, Eaton K, Chen S, Salay TM, Alaparthy S, Grosso JF, Korman AJ, Parker SM, Agrawal S, Goldberg SM, Pardoll DM, Gupta A, Wigginton JM. Safety and activity of anti-PD-L1 antibody in patients with advanced cancer. N Engl J Med 2012;366:2455-65.

86. Royal RE, Levy C, Turner K, Mathur A, Hughes M, Kammula US, Sherry RM, Topalian SL, Yang JC, Lowy I, Rosenberg SA. Phase 2 trial of single agent Ipilimumab (anti-CTLA-4) for locally advanced or metastatic pancreatic adenocarcinoma. J Immunother 2010;33:828-33.

87. Gunturu KS, Rossi GR, Saif MW. Immunotherapy updates in pancreatic cancer: are we there yet? Ther Adv Med Oncol 2013;5:81-9.

88. Hardacre JM, Mulcahy M, Small W, Talamonti M, Obel J, Krishnamurthi S, Rocha-Lima CS, Safran H, Lenz HJ, Chiorean EG. Addition of algenpantucel-L immunotherapy to standard adjuvant therapy for pancreatic cancer: a phase 2 study. J Gastrointest Surg 2013;17:94-100; discussion 100-1.

89. Dalgleish AG, Stebbing J, Adamson DJ, Arif SS, Bidoli P, Chang D, Cheeseman S, Diaz-Beveridge R, Fernandez-Martos C, GlynneJones R, Granetto C, Massuti B, McAdam K, McDermott R, Martín AJ, Papamichael D, Pazo-Cid R, Vieitez JM, Zaniboni A, Carroll KJ, Wagle S, Gaya A, Mudan SS. Randomised, open-label, phase II study of gemcitabine with and without IMM-101 for advanced pancreatic cancer. Br J Cancer 2016;115:e16.

90. Le DT, Wang-Gillam A, Picozzi V, Greten TF, Crocenzi T, Springett G, Morse M, Zeh H, Cohen D, Fine RL, Onners B, Uram JN, Laheru DA, Lutz ER, Solt S, Murphy AL, Skoble J, Lemmens E, Grous J, Dubensky T Jr, Brockstedt DG, Jaffee EM. Safety and survival with GVAX pancreas prime and Listeria Monocytogenes-expressing mesothelin (CRS-207) boost vaccines for metastatic pancreatic cancer. J Clin Oncol 2015;33:1325-33.

91. Polireddy K, Chen Q. Cancer of the pancreas: molecular pathways and current advancement in treatment. J Cancer 2016;7:1497-514.

92. Singha NC, Nekoroski T, Zhao C, Symons R, Jiang P, Frost GI, Huang Z, Shepard HM. Tumor-associated hyaluronan limits efficacy of monoclonal antibody therapy. Mol Cancer Ther 2015;14:523-32.

93. Pitt JM, Marabelle A, Eggermont A, Soria JC, Kroemer G, Zitvogel L. Targeting the tumor microenvironment: removing obstruction to anticancer immune responses and immunotherapy. Ann Oncol 2016;27:1482-92.

94. Albini A, Sporn MB. The tumour microenvironment as a target for chemoprevention. Nat Rev Cancer 2007;7:139-47.

95. Wong KM, Horton KJ, Coveler AL, Hingorani SR, Harris WP. Targeting the tumor stroma: the biology and clinical development of 
pegylated recombinant human hyaluronidase (PEGPH20). Curr Oncol Rep 2017;19:47.

96. Hingorani SR, Zheng L, Bullock AJ, Seery TE, Harris WP, Sigal DS, Braiteh F, Ritch PS, Zalupski MM, Bahary N, Oberstein PE, Wang-Gillam A, Wu W, Chondros D, Jiang P, Khelifa S, Pu J, Aldrich C, Hendifar AE. HALO 202: Randomized phase II study of PEGPH20 plus nab-paclitaxel/gemcitabine (PAG) vs AG in patients with untreate, metastatic pancreatic ductal adenocarcinoma (mPDA). J Clin Oncol 2017;35 suppl:abstr4008.

97. de Geus, SWL, Eskander, MF, Kasumova GG, Ng SC, Kent TS, Mancias JD, Callery MP, Mahadevan A, Tseng JF. Stereotactic body radiotherapy for unresected pancreatic cancer: a nationwide review. Cancer 2017;123:4158-67.

98. Zhong J, Patel K, Switchenko J, Cassidy RJ, Hall WA, Gillespie T, Patel PR, Kooby D, Landry J. Outcomes for patients with locally advanced pancreatic adenocarcinoma treated with stereotactic body radiation therapy versus conventionally fractionated radiation. Cancer 2017;123:3486-93.

99. Sugawara A, Kunieda E. Effect of adjuvant radiotherapy on survival in resected pancreatic cancer: a propensity score surveillance, epidemiology, and end results database analysis. J Surg Oncol 2014;110:960-6.

100. Baschnagel A, Shah C, Margolis J, Nadeau L, Stein J, Jury R, Robertson JM. Survival after chemoradiation in resected pancreatic cancer: the impact of adjuvant gemcitabine. Int J Radiat Oncol Biol Phys 2012;83:E331-5.

101. Ng SP, Herman JM. Stereotactic radiotherapy and particle therapy for pancreatic cancer. Cancers (Basel) 2018;10:E75.

102. Hammel P, Huguet F, van Laethem JL, Goldstein D, Glimelius B, Artru P, Borbath I, Bouché O, Shannon J, André T, Mineur L, Chibaudel B, Bonnetain F, Louvet C; LAP07 Trial Group. Effect of chemoradiotherapy vs chemotherapy on survival in patients with locally advanced pancreatic cancer controlled after 4 months of gemcitabine with or without ErlotinibThe LAP07 randomized clinical trial. JAMA 2016;315:1844-53.

103. Huguet F, André T, Hammel P, Artru P, Balosso J, Selle F, Deniaud-Alexandre E, Ruszniewski P, Touboul E, Labianca R, de Gramont A, Louvet C. Impact of chemoradiotherapy after disease control with chemotherapy in locally advanced pancreatic adenocarcinoma in GERCOR phase II and III studies. J Clin Oncol 2007;25:326-31.

104. Krishnan S, Rana V, Janjan NA, Varadhachary GR, Abbruzzese JL, Das P, Delclos ME, Gould MS, Evans DB, Wolff RA, Crane CH. Induction chemotherapy selects patients with locally advanced, unresectable pancreatic cancer for optimal benefit from consolidative chemoradiation therapy. Cancer 2007;110:47-55. 